Please do not remove this page

RMIT

UNIVERSITY

\title{
Corporate reputation and organisational performance: an Australian study
}

Inglis, Robert; Morley, Clive; Sammut, Paul

https://researchrepository.rmit.edu.au/esploro/outputs/9921859538001341/filesAndLinks?institution=61RMIT_INST\&index=null

Inglis, R., Morley, C., \& Sammut, P. (2006). Corporate reputation and organisational performance: an Australian study. Managerial Auditing Journal, 21(9), 934-947.

https://doi.org/10.1108/02686900610705028

Published Version: https://doi.org/10.1108/02686900610705028

Repository homepage: https://researchrepository.rmit.edu.au

(c) Emerald Group Publishing Limited

Downloaded On 2023/04/26 23:18:02 +1000 
Inglis, R, Morley, C and Sammut, P 2006, 'Corporate reputation and organisational performance: an Australian study', Managerial Auditing Journal, vol. 21, no. 9, pp. 934-947.

\title{
Corporate reputation and organisational performance: An Australian study
}

\author{
Inglis, R, Morley, $\mathrm{C}$ and Sammut, $\mathrm{P}$. \\ RMIT University
}

\begin{abstract}
Purpose: $\quad$ To test for a relationship between corporate reputation and financial performance, using Australian data.
\end{abstract}

Methodology: Econometric modeling.

Findings: No causal relationship between corporate reputation and financial performance (in either direction) was found. This is contrary to some findings in other countries. Reputation may not have a significant impact on performance in Australia There may be weaknesses in the existing measure of reputation, or the finding may be due to unobserved variability in the intervening variable of managerial exploitation of the reputation.

Research limitations: The findings may be specific to Australia. In Australia, the linkage between reputation and performance may be too small to be significant in the available sample.

Practical implications: The authors argue that in corporate practice the link between reputation and performance proceeds via strategy and competitive advantage. Having a reputation resource is not enough; it needs to be managed well and exploited if it is to yield financial results. More work is needed to establish reliable measures of reputation.

Originality/value: This is the first known study to investigate the link on Australian data. The discussion of the findings raises issues for the measurement and management of reputation.

Keywords: corporate reputation, financial performance, Reputex, strategy

Classification: Research paper 


\section{Introduction}

Reputation is seen by many commentators as an important asset which could be used as a competitive advantage and a source of financial performance. A "good" reputation is identified as an intangible resource which may provide the organisation with a basis for sustaining competitive advantage given its valuable and hard to imitate characteristics (Hall, 1993; Barney 1991). A growing body of literature has been concerned with organisational reputation as a valuable resource and its association with financial performance (Roberts and Dowling, 2002; Eberl and Schwaiger 2005).

Benefits of a good reputation are seen as including higher customer retention rates and associated increased sales and product selling prices (Shapiro, 1983), and reduced operating costs (Podony, 1993). Notwithstanding these potential benefits, questions continue to be raised about the adequacy of the reputation construct (Gotsi and Wilson, 2001), how the benefits of corporate reputation are realised financially (Eberl and Schwaiger, 2005) and the direction of the reputation-performance relationship.

Following the approach adopted by Rose and Thomsen (2004), this study examines Australian data to ascertain any relationship between reputation and organisational performance. The paper commences with a review of the extant literature on reputation, its definition, measurement and association with financial performance. We then describe the method and data sources used in the study, followed by an analysis and summary of the results. This is followed by a discussion of the findings and a brief review of two industrybased cases which illustrate points of the discussion. We conclude by discussing the implications of the research.

\section{Literature review}

On-going issues within the corporate reputation research literature centre on the definition of the reputation construct, the way in which reputation is operationalised and the contribution of reputation to organisation success. Shenkar and Yuchtman-Yaar (1997) use the term "standing" as a generic term for a number of concepts - image, prestige, goodwill associated with corporate reputation in various disciplines, e.g., marketing, economics and accounting. A number of differences which distinguish disciplinary approaches are identified, including the unit of analysis (individual, brand, firm), the point in time at which 
reputation is considered (past, present, future) and constituencies (range of stakeholders or “validating groups" Perrow 1961).

Several of these differences are encapsulated in Fombrun's (1990, p 72) much adopted definition of reputation as "a perceptual representation of a company's past actions and future prospects that describe the firm's overall appeal to all its key constituents when compared to other leading rivals". There seems to be a general consensus within the literature that reputation can be defined in terms of its perceptual nature, i.e., "the empirical truth of corporate reputation comes from whatever the respondents say" (Wartick, 2002, p 375), which develops from "direct experiences with the company, any other form of communication and symbolism that provides information about the firm's actions and/or a comparison with the actions of other leading rivals" (Gotsi and Wilson, 2001, p 25).

However, significantly more debate surrounds the identification, equivalency, and diversity of views of constituents from whom the perceived reputation is developed. Wartick (2002) highlights the differing effects and shortcomings that may result from applying weightings to the reputation perceptions of a range of stakeholder groups (community, owners, customers, suppliers, employees) in formulating "a grand aggregate definition of corporate reputation" and emphasises "how important the construction of the definition is for measurement purposes" (p.378-9). Aggregation clarifies and often makes the data usable, but at the possible expense of averaging out view diversity and its information content.

The literature also reveals on-going criticism of the existing measurement constructs (see, for instance, Eidson and Master, 2000; Schwaiger, 2004) and the items of which they are composed. In considering the issue of item composition, Groenland (2002) proposes the use of a "reputation quotient" encompassing six dimensions: emotional appeal, products and services, vision and leadership, workplace environment, social and environmental responsibility, and financial performance. Similar in concept to Groenland's reputation quotient, Australia's "RepuTex" construct, the focus in this study, encompasses four dimensions; corporate governance, workplace practices, social impact and environmental impact (RepuTex 2006).

Notwithstanding the issues surrounding definition and measurement, a "good" reputation is proffered as a basis for competitive advantage and increased profitability. Barney (1991) 
identifies reputation as one of a number of valuable, rare, inimitable, and non-substitutable intangible resources which can provide a sustained competitive advantage. As a socially complex resource, a positive reputation can be a major factor in sustaining competitive advantage as it is developed over a long period of time that cannot be easily shortened by competitors (Dierickx and Cool, 1989; Hall 1992). In linking reputation to Coyne's (1986) notion of positional capability as a source of sustainable competitive advantage, Hall (1992 p614) finds that reputation is "rated highly with respect to the contribution it makes to business success".

However, the extent to which reputation, as a source of competitive advantage, can be associated with a firm's financial performance requires further research. Purported benefits that flow from possessing a "good" reputation and which have been associated with increased financial performance include: providing an indicator of product quality when consumers are faced with a choice between competing products (increased sales, premium prices and customer retention) (Shapiro, 1983); the attraction of higher calibre staff and higher staff retention rates (reduced organisational costs) (Roberts and Dowling, 2002); reduction of supplier and buyer exchange uncertainty (increased sales, reduced transaction costs) (Kotha et al, 2001); and providing a reserve of goodwill (strategic intangible asset) as a competitive "barrier" in challenging operating times (maintaining sales) (Michalisin et al, 2000).

Podolny (1993) identifies the inverse relationship between "status" and costs, wherein highstatus firms have lower costs (e.g., transaction, financial, advertising and employee costs) providing an incentive for such firms to further enhance their reputations. This indicates that once a company develops a good reputation, it will reap benefits, which will in turn further improve the reputation. But it is unclear how well this is actually done by companies and if the realisation of benefits occurs in practice.

The issue of an interrelationship between financial performance and reputation (the so called "reputational vicious circle") is noted by Roberts and Dowling (2002) wherein improved profitability also enhances reputation which, in turn, enhances the maintenance of financial performance over time. They find, however, that very little of the variance in the reputation measure is explained by prior years profits. Using market to book value of equity as the measure of performance, Rose and Thomsen (2004) produce results that "challenge 
conventional wisdom" ( $\mathrm{p} 208$ ) in that corporate reputation was not found to improve financial performance; however, financial performance was found to affect reputation.

Following the approach adopted by Roberts and Dowling (2002), Eberl and Schwaiger (2005 p845) “disentangle the 'reputational' and 'financial' effects on future performance" in examining the influence of both cognitive and affective dimensions of corporate reputation and past and current financial performance. They proffer that past financial performance is only one of a number of components of company reputation and that while the cognitive dimension has a positive influence on future financial performance, the affective dimension has a negative impact (Eberl and Schwaiger (2005 p851).

\section{Method and Data}

This study parallels a recent investigation by Rose and Thomsen (2004) into the impact of corporate reputation on financial performance. Their analysis used a public image rating of leading Danish companies formulated from questionnaire responses of Danish business managers.

This study is based on Australian data and combined two pre-existing data sources. The first is a reputation ratings index produced annually by an Australian private company - RepuTex - based upon ratings from a range of community and business groups (see Appendix 1) on four key dimensions - corporate governance, workplace practices, social impact and environmental impact. Each dimension encompasses a range of items (see Appendix 2) which take account of past and future risk relating to social responsibility (RepuTex, 2006) and is consistent with the Fombrun's(1996) definition of reputation and categorically similar to Groenland's (2002) reputation quotient. The use of an established reputation database ruled out the examination of the cognitive and affective dimensions in the current study.

Substantial change to the RepuTex ratings in 2003 precluded the use of data for prior years and restricted the study to a two-year period. In 2003, a rating (from AAA to D) was assigned to each organisation, while in 2004 an additional + or - was used in order to provide a greater degree of differentiation between firms. The role of community groups was substantially reduced in 2004 with their involvement reduced to one of comment on the assessment criteria wording and weightings. Research analysts and RepuTex researchers 
were increasingly involved in data collection and the assignment of ratings against four key dimensions prior to final assignment of ratings by a reviewing committee. The final rating criteria took into account relative and consistent firm standings within the sector and across dimensions (Reputex, 2006). Given the changes in the development of the reputation ratings over the 2003 and 2004 years, the reliability of the reputation data may be brought into question. To examine the effects of the changes in the ratings process, a comparison of the 2003 and 2004 ratings was undertaken across the four dimensions and the overall dimension rating for each firm.

The second data set was financial information. Operational measures of financial performance vary across studies but generally draw on both market and firm -specific financial measures. Hall (1993) suggests reputation, as one of a number of intangibles, is reflected in the excess of the market valuation of a publicly listed company over its balance sheet value of ordinary capital and reserves. The market to book value measure has been consistently used in studies of reputation and performance (see, for example, Roberts and Dowling, 2002; Rose and Thomsen, 2004) and is adopted in the current study. Financial benefits associated with a positive reputation potentially include increased sales, profit and return on investment; information which can be determined from companies' published financial statements. Despite the criticisms of traditional accounting measures of performance in terms of consistency of calculation and adherence to accounting policies, return measures (return on assets, equity and invested capital) continue to be widely used and were adopted in this study to encapsulate revenue, cost and investment elements of performance.

Financial information for the second data set was extracted from AspectHuntley's "Fin Analysis", a database which provides audited detailed financial information for all companies listed on the Australian Stock Exchange (ASX). Three measures of financial performance - return on equity (ROE), return on assets (ROA) and return on invested capital (ROIC) - were extracted directly from Fin Analysis. The fourth measure of performance market to book value of equity (MBV) - was developed by extracting the market value of the firm directly from Fin Analysis and extracting and combining the components of the book value of equity (ordinary share capital, reserves - excluding share premium reserves - and retained earnings) from Fin Analysis. 
The literature suggests that the direction of impact could flow in either direction, that is, that reputation could affect performance, or performance could affect reputation. Therefore, two hypotheses are proposed for testing:

Hypothesis 1 - A higher (lower) reputation leads to higher (lower) financial performance;

Hypothesis 2 - A higher (lower) financial performance leads to higher (lower) reputation.

\section{Analysis and Results}

\section{Sample}

Selection was done on the basis of the required data being available. A sample of 77 companies was selected for analysis. These 77 companies are those that were listed on the Australian Stock Exchange (ASX) in both the years 2003 and 2004 and were rated by RepuTex in both years. For some companies not all the performance data was available and the consequential missing values means that the analyses reported below were done on samples ranging from 54 to 77.

\section{Reputation variable}

The data available has a Reputation Overall variable, which is a categorical variable taking one of six values for each company. This is a summary of four component variables, with values (again in six categories) for each company on each of the four dimensions of Governance, Environment, Social and Workplace. To provide quantitative data for testing the hypotheses in a regression model, the categorical values were translated into integer scores ranging from zero to six (see Table 1). In place of using the given Reputation Overall variable, the scores on the four dimensions were used to construct an Image variable as the sum of the four components. The Image variable has the advantage of a much wider spread of values and hence more power in regression models.

$<$ Take in Table 1 here $>$ 
The appropriateness of this approach was confirmed by analysis. Factor analysis on the four components of Reputation found one factor which explained a large part of the variance and which all four components loaded on strongly. For the 2004 data, the eigenvalue of this factor was 2.350 (the next largest was 0.725 ) explaining $59 \%$ of the total variation.

Loadings of the dimensions on this factor were:

$\begin{array}{ll}\text { Governance } & 0.803 \\ \text { Environment } & 0.781 \\ \text { Social } & 0.827 \\ \text { Workplace } & 0.640\end{array}$

The Cronbach alpha is 0.731 , confirming that the four can be reliably combined into a single, uni-dimensional scale.

Very similar results were obtained for the 2003 data. There was one factor with an eigenvalue of 2.199 (the next largest was 0.754 ) explaining $55 \%$ of total variation. The loadings were all over 0.6 and the Cronbach alpha was 0.642 . Therefore, a variable Image $\left(I_{i}\right)$ was constructed with a value for each company (i) the sum of the four reputation components. This is the variable used in the subsequent analyses. As a score (with a possible range of 0 to 24 ) it is a better measure of reputation than a ranking (as used in Rose and Thomsen 2004) for regression purposes.

\section{Performance variable}

Four measures of corporate performance were investigated. Market to book value (MBV) following Rose and Thomsen (2004), Return on Assets (ROA), Return on Equity (ROE) and Return on Invested Capital (ROIC). The performance measures are strongly correlated with their lags and generally with each other, with the partial exception of ROIC which is not always correlated with the other performance measures (see Table 2; the suffixes 03 and 04 denote the years 2003 and 2004 respectively).

$<$ Take in Table 2 here $>$ 
The results for MBV, ROA and ROE can thus be expected to be very similar (as is indeed found in the analysis reported below).

\section{Models}

Following the specification of Rose and Thomsen (2004), two equations are estimated:

Model 1: $\mathrm{Q}_{\mathrm{i}}=\alpha_{1}+\beta_{1} \mathrm{I}_{\mathrm{i}}+\beta_{2} \mathrm{Q}_{\mathrm{i}}^{1}+\mathrm{e}_{1 \mathrm{i}}$

Model 2: $\mathrm{I}_{\mathrm{i}}=\alpha_{2}+\beta_{3} \mathrm{I}_{\mathrm{i}}^{1}+\beta_{4} \mathrm{Q}_{\mathrm{i}}^{1}+\mathrm{e}_{2 \mathrm{i}}$

in which $\mathrm{Q}_{\mathrm{i}}$ is the performance measure, in turn MBV04, ROA04, ROE04 and ROIC04, and $\mathrm{Q}_{\mathrm{i}}^{1}$ is the same performance measure lagged by one year (i.e. respectively MBV03, ROA03, ROE03 and ROIC03); $I_{i}$ is the Image variable for 2004 and $I_{i}^{1}$ the lagged Image (i.e. for 2003). This formulation is effectively setting up tests for Granger causality (Granger 1969) in which causality is ascribed if the values of a variable affect the subsequent values of another variable. That is, in this application, if $\beta_{1} \neq 0$ and $\beta_{4}=0$ we would infer causality in the single direction of Image affecting performance, whilst if $\beta_{1}=0$ and $\beta_{4} \neq 0$ we would infer causality in the single direction of performance affecting Image. If $\beta_{1} \neq 0$ and $\beta_{4} \neq 0$, then we would infer causality running in both directions.

The results and significance of the four $\beta$ co-efficients from the regression estimations are shown in Table 3.

\section{$<$ Take in Table 3 here $>$}

In each model, for each performance measure, the lagged dependent variable is significant, but not the other potential explanatory variable. That is, Image does not significantly affect performance, nor does performance significantly affect Image. Both hypothesis 1 and hypothesis 2 are thus rejected. The latter result is different to the Danish finding of Rose and Thomsen (2004).

A number of variations of the models were estimated, but none of these affected the pattern of significant co-efficients. Rose and Thomsen (2004) suggested that Size could be an important variable in the relationships modelled. This was investigated in the analysis. Equity (calculated as the average equity over the two years) was too strongly correlated with 
the performance measures to be used in the regression models, so the rank of this Equity was used as the size variable. Size was not significant in any of the versions of model 1 , and its inclusion did not change the finding that lagged performance is significant, but Image is not. The size variable was significant in all four versions of Model 2, but whilst this improved the fit $\left(\mathrm{R}^{2}\right)$ it did not change the finding that the lagged Image was significant and the lagged performance not significant. Alternatively, the rank of company assets was used as the size variable, with the same results (with the possible exception that in estimating model 2 lagged ROIC was significant at the $5 \%$ level, but not at the $1 \%$ level: $p=0.031$ ).

Arguably (for example, in Shapiro, 1983 and Kotha et al, 2001), the effects of reputation more directly impact on sales than performance. To consider this possibility, company annual Revenue was inserted in place of the performance variables $\left(Q_{i}\right)$ into models 1 and 2 . Revenue data was sourced from the Fin Analysis data base. It was noted that Revenue was highly correlated with MBV, but not with the other performance measures (those based on returns), so expectations were low that using revenue would change the results. Indeed, in the regressions for the two models, Revenue was not a significant predictor of Image, nor was Image a significant predictor of Revenue.

The findings from all models were not affected by the removal from consideration of a high leverage case (one company with exceptionally high returns). The rank of the Image variable was tried in place of Image itself (following Rose and Thomsen, 2004) but had no effect on the significance of the variables. Nor did using the log of the performance variables change the findings. The findings thus appear to be reasonably robust to variants of the model and variables.

There was a change in the process of determining ratings over the two years, with reduced input from community groups as stakeholders in 2004 and an increased involvement by RepuTex researchers and analysts. Analysis was undertaken of the reputation data set to examine whether the change in the process of determining the RepuTex ratings could have affected the results. Between 2003 and 2004 there was a small decrease in average scores across all dimensions, but statistical tests (using matched pairs t-tests and a significance level of 5\%) revealed no significant differences on any of the dimensions over the two years. The change in the ratings process does not appear to have impacted on the results. 
The modelling used lagged variables in the Granger causality approach to address the endogeneity problem of not knowing which variable (reputation or financial performance) is driving the other. Two stage regression could be used as an alternative way to estimate the system of the two equations (after re-specification). But this would require data on many more relevant variables, to establish sound proxies in the first stage, and in departing from the method used in other studies would potentially lessen the comparability of the results.

\section{Discussion}

The results in the current study fail to establish any relationship between reputation and performance, i.e., reputation does not affect financial performance nor does financial performance affect reputation. This is inconsistent with the findings of Rose and Thomsen (2004) whose research approach was adopted in this study. The lack of significance in the findings may be due to a smaller sample size requiring the effect to be larger to be significant.

This study raises questions about the reliability of associating measures of reputation with organisational financial performance. While Rose and Thomsen (2004) question the costbenefit of investing in reputation and advocate increased management attention to improving financial performance, we would suggest a greater focus is required on how reputation, as a source of sustainable competitive advantage, has been managed to yield improved financial performance. That is, reputation, as an intangible resource providing a positional capability differential (Hall, 1993), needs to be leveraged in such a way as to generate above-average profits, yet how this is currently operationalised in firms is not well explicated. This leverage management is a missing intermediary factor between reputation and financial performance. It may be the case, for example, that while firms have developed a positive reputation, it is not perceived by constituents as being as a significant differentiator from competitors and brings into question how organisational management have strategically managed this resource. 
Industry cases continue to be publicly reported that cast further doubt on the reputationperformance link and raise questions as to how well the reputation advantage has been exploited. Two short cases from the banking industry are presented.

\section{Westpac Bank}

The Westpac Banking Corporation received the following ratings from RepuTex in 2003 and 2004:

\section{$<$ Take in Table 4 here $>$}

Westpac was the leading company in both the 2003 and 2004 RepuTex surveys with its main competitors receiving lower ratings. However, recent reports indicate that Westpac is losing market share. Moullakis (2005) writing in the Australian Financial Review noted that:

Westpac has lost ground in the battle for deposits and home loans, seeing its market share across both sectors fall by 1 per cent since September. According to ABN Amro's analysis of the most recent Australian Prudential Regulation Authority data, Westpac's share of total deposits slipped to 15.7 per cent, while its home lending share fell to 17.9 per cent. ABN Amro has since questioned how long it would take for the bank to breathe life into its sagging mortgage business. National Australia Bank meanwhile recorded strong growth across its business lending unit, giving it a 20.2 per cent share of the market from September to the end of April. ANZ was placed second with a market share of 18.4 per cent $(\mathrm{p} 45)$.

If consumer decisions were made on reputation, it would not be unreasonable to expect Westpac to have the dominant market share and the others to trail behind. The fact that Westpac is not dominant in the market suggests that factors other than reputation may taken much more into account by consumers when their decisions are made and/or that Westpac have not exploited their Reputation advantage. From the corporate perspective, either the high reputation is not a true reflection of the company's real reputation, reputation is not important in building sustained financial results, or the reputation is not being managed well and used to drive financial results. 
National Australia Bank (NAB)

The NAB received the following ratings from RepuTex in 2003 and 2004.

$<$ Take in Table 5 here $>$

On Friday 9 January 2004, at a time when the NAB Governance Rating was G2 (high), an employee discovered fraudulent activity, largely attributed to a breakdown in internal controls in the currency trading area of the firm. The reported consequences for NAB included:

- a financial loss of \$A360million;

- the CEO was replaced;

- the Chairman of the Board was replaced;

- the traders involved and those who supervised them lost their jobs; and

- the NAB suffered negative media reports and commentary.

There was no hint in the RepuTex ratings that NAB would suffer such losses. It is difficult to be critical of the RepuTex rating given that these losses took all stakeholders (except for the traders themselves), including the management of the company, by surprise. NAB subsequently embarked on a series of major changes, replacing key staff and addressing key weaknesses in internal control and cultural issues.

Reputex (2004) made the following comments in the 2004 Report for NAB:

National Australia Bank has faced a challenging year with governance issues, including some of the requirements of the Australian Prudential Regulatory Authority (APRA), still outstanding. In response, it has altered the structure of the company to strengthen the audit and risk management systems, and to provide a greater degree of oversight with more comprehensive reporting systems. It has also reviewed the incentive systems within the company. The outcomes of these changes remain to be seen, and the assessment for Corporate Governance this year is reflected in National Australia Bank's lower score.

In the NAB case there is seen a company that had a lower reputation than its close counterpart in the same industry, Westpac, yet was achieving higher performance. Also, the 
NAB rated highly on its corporate governance reputation, but its internal controls actually failed disastrously. The rating of this aspect of reputation was lagging well behind reality and had no predictive power.

In the above cases, major business problems are seen to affect the performance, strategy and share price of the company, but the linkages (forward or backward) with reputation appear tenuous.

\section{Conclusion}

In Australia, the best known attempt to measure reputation is the service called Reputex. A typical view is that expressed by Parker (2005):

(There is) the Reputation Index known as RepuTex whose ratings are seen as having significant effect on share prices indicating that financial commentators and analysts are ready to look beyond traditional business performance indicators.

It is difficult to support this assertion given the results in this paper. It may be conceded that commentators do look beyond traditional business performance indicators, but the direct relationship suggested has not been established. Statistical modelling fails to find any significant relationship between the measure of reputation and financial performance. Contrary cases are readily provided.

This finding could be due to flaws in the reputation measure, or due to weaknesses in the linkage. There are at least two questions the devisors and users of the Reputex measure need to consider. Firstly, are the factors and dimensions used the right ones, especially as they relate to competitive advantage and performance? Although the dimensions of the Reputex rating do appear to have a certain face validity at least, the underlying variables considered (Appendix 2) may be less clearly the appropriate ones. Secondly, is the scoring giving an accurate reflection of reality? The community and business groups involved in the giving of scores (Appendix 1) may not be the optimum for achieving community scoring. The list could be considered for representativeness as well as willingness to be involved and expertise. Are these organisations and their representatives the best spread and mix of scorers? 
With regard to possible weaknesses in the link between corporate reputation and performance, we argue that the link is not, in corporate practice, direct, but proceeds via strategy and competitive advantage. The resource that is reputation needs to be exploited if it is to yield financial results. Having the resource is not enough; it needs to be managed well. The level of use and management of reputation is, from this perspective, a key intervening factor. 


\section{Appendix 1 Community and Business Groups}

The Community and Business groups involved in ratings were:

\section{Corporate Governance}

- Australian Shareholders Association

- The Ethics Network, University of Melbourne Centre for Applied Philosophy and Public Ethics

- Institute for International Corporate Governance and Accountability

- Institute of Chartered Accountants (financial measures only)

- Securities Institute of Australia

- UTS Centre for Corporate Governance

\section{Environmental Impact}

- EPA Victoria

- Greenpeace

- RMIT University

- Total Environment Centre

- The Wilderness Society

\section{Social Impact}

- Australia Business Arts Foundation

- Australian Council of Social Services

- Victoria University, Industry Education Partnerships

\section{Workplace Practices}

- Australian Council of Trade Unions

- Australian Institute of Management

- Diversity@work

- Monash University Accident Research Centre

- Standards Australia

The various business and community groups met with RepuTex to finalise the questions, scoring scales and criteria. These groups developed findings based on a combination of their own data and the data collected by RepuTex.

The RepuTex Rating Committee developed a statistical model to assign ratings against the RepuTex rating scale. 


\section{Appendix 2 Ratings dimension items}

\section{Corporate Governance}

- Ethical Business Conduct

- Ownership of Organisation

- Organisational Structure and Management

- Risk and Financial Management

- Audit and Compliance

- Shareholder Relations and Reporting

\section{Environmental Impact}

- Policy

- Environmental Management System

- Voluntary Codes

- Product Stewardship and Life Cycle Assessment

- Sustainability Investing

- Commitment to Ecologically Sustainable Development

\section{Social Impact}

- Community Investment and Philanthropic Support

- Human Rights

- Consumer Rights, Access and Empowerment

- Stakeholder Engagement and Social Reporting

\section{Workplace Practices}

- Employee Development and Training

- Workplace Relations and Remuneration

- Organisational Culture and Diversity

- Occupational Health and Structure 


\section{References}

Barney, J. 1991 Firm resources and sustainable competitive advantage. Journal of Management, 17, 99-120.

Coyne, K. 1986 Sustainable competitive advantage - What it is and what it isn't. Business Horizons, Jan/Feb, 54-61.

Dierickx, I and Cool, K 1989 Asset stock accumulation and sustainable competitive advantage. Management Science, 38, 1504-1511.

Eberl, M. and Schwaiger, M. 2005 Corporate reputation: disentangling the effects on financial performance. European Journal of Marketing, 39, 7/8, 838-854.

Eidson, C. and Master, M. 2000 Top ten...most admired...most respected: who makes the call? Across the Board, 37, 3, 16-22.

Fombrun, C. and Shanley, M. 1990 What's in a name? Reputation building and corporate strategy. Academy of Management Journal, 33, 2, 233-258.

Fombrun, C. 1996 Reputation: Realizing value from corporate image, Boston, Harvard Business School Press

Gotsi, M. and Wilson, A. 2001 Corporate reputation: Seeking a definition. Corporate Communications, 6, 1, 24-30.

Granger, C.W.J. 1969 Investigating causal relations by econometric models and crossspectoral methods. Econometrica, 37, 24-36.

Groenland, E. 2002 Qualitative research to validate the RQ-dimensions. Corporate Reputation Review, 4, 4, 308-315.

Hall, R. 1992 The strategic analysis of intangible resources. Strategic Management Journal, $13,135-144$.

Hall, R. 1993 A framework linking intangible resources and capabilities to sustainable competitive advantage. Strategic Management Journal, 14, 607-618

Kotha, S., Rajgogal, S. and Rindova, V. 2001 Reputation building and performance: an empirical analysis of the top-50 pure internet firms. European Management Journal, 19, 6, 570-586.

Michalisin, M., Kline, D. and Smith, R.. 2000 Intangible strategic assets and firm performance: a multi industry study of the resource based view. Journal of Business Strategies, 17, 2, 93-117.

Moullakis, J. 2005 Westpac loses ground to rivals. Australian Financial Review, 2 August, $\mathrm{p} 45$. 
Parker, D. 2005 Sustainability gets a boost as agency sets up new report centre. The Australian, 3 June, p30

Perrow, C. 1961 Organizational prestige: Some functions and dysfunctions. American Journal of Sociology, 66, 335-341.

Podony, J. 1993 A status-based model of market competition. American Journal of Sociology, 98, 4, 829-872.

Roberts, P. and Dowling, G. 2002 Corporate reputation and sustained superior financial performance. Strategic Management Journal, 23, 1077-1093.

Rose, C. and Thomsen, S. 2004 The impact of corporate reputation on performance: Some Danish evidence. European Management Journal, 22, 2, 201-210.

RepuTex 2004 National Australia Bank. http://www.reputex.com.au/pdfs/2004/WebNational\%20Australia\%20Bank\%20 Ltd\%20RepuTex\%202004.PDF accessed 12 May 2005

RepuTex 2006 RepuTex Methodology. https://secure1.impactdata.com.au/reputex/ accessed 16 February 2006

Schwaiger, M. 2004 Components and parameters of corporate reputation - an empirical study. Schmalenbach Business Review, 56 46-71.

Shapiro, C. 1983 Premiums for high quality products as returns to reputations. Quarterly Journal of Economics, 98, 4, 659-679.

Shenkar, O. and Yuchtman-Yaar, E. 1997, Reputation, image, prestige, and goodwill: an interdisciplinary approach to organizational standing. Human Relations, 50, 11, 1361-1381.

Wartick, S. 2002 Measuring corporate reputation. Business and Society, 41, 4, 371-392. 
Table 1 Scores equivalent for the RepuTex ratings

\begin{tabular}{|l|c|c|c|c|c|c|c|}
\hline Scores Allocated & $\mathbf{6}$ & $\mathbf{5}$ & $\mathbf{4}$ & $\mathbf{3}$ & $\mathbf{2}$ & $\mathbf{1}$ & $\mathbf{0}$ \\
\hline Overall & AAA & AA & A & B & C & D & I/A \\
\hline Governance & G1 & G2 & G3 & G4 & G5 & G6 & I/A \\
\hline Social & S1 & S2 & S3 & S4 & S5 & S6 & I/A \\
\hline Environmental & E1 & E2 & E3 & E4 & E5 & E6 & I/A \\
\hline Workplace & W1 & W2 & W3 & W4 & W5 & W6 & I/A \\
\hline
\end{tabular}

Table 2. Correlations amongst performance measures

\begin{tabular}{l|lllllll} 
& MBV03 & MBV04 & ROA03 & ROA04 & ROE03 & ROE04 & ROIC03 \\
\hline MBV04 & $0.923^{* * *}$ & & & & & & \\
ROA03 & $0.327 * *$ & $0.364 * *$ & & & & & \\
ROA04 & $0.382^{* *}$ & $0.475^{* * *}$ & $0.736^{* * *}$ & & & & \\
ROE03 & $0.519 * * *$ & $0.535^{* * *}$ & $0.786^{* * *}$ & $0.456^{* * *}$ & & & \\
ROE04 & $0.611^{* * *}$ & $0.724 * * *$ & $0.505^{* * *}$ & $0.681 * * *$ & $0.696 * * *$ & & \\
ROIC04 & $0.383^{* *}$ & $0.414^{* *}$ & $0.631^{* * *}$ & 0.254 & $0.687 * * *$ & $0.405^{* *}$ & \\
ROIC03 & $0.392^{* *}$ & $0.334 *$ & 0.171 & 0.120 & 0.228 & 0.247 & $0.610^{* * *}$ \\
\hline
\end{tabular}

$$
* \mathrm{p}<0.05 ; * * \mathrm{p}<0.01 ; * * * \mathrm{p}<0.001
$$


Table 3. Regression results

\begin{tabular}{|c|c|c|c|c|}
\hline Model 1 & \multicolumn{2}{|c|}{ estimated co-efficient ( $p$ value) } & \multirow[t]{2}{*}{$\mathrm{R}^{2}$} & \multirow[t]{2}{*}{$\mathrm{N}$} \\
\hline Q & $\beta_{1}$ & $\beta_{2}$ & & \\
\hline MBV & $-0.003(0.869)$ & $0.773(0.000)$ & 0.865 & 63 \\
\hline ROA & $-0.001(0.949)$ & $0.623(0.000)$ & 0.540 & 64 \\
\hline ROE & $0.001(0.518)$ & $0.537(0.000)$ & 0.516 & 64 \\
\hline ROIC & $0.000(0.997)$ & $1.026(0.000)$ & 0.365 & 53 \\
\hline$\underline{\text { Model } 2}$ & \multicolumn{2}{|c|}{ estimated co-efficient ( $\mathrm{p}$ value) } & $\mathrm{R}^{2}$ & $\mathrm{~N}$ \\
\hline Q & $\beta_{3}$ & $\beta_{4}$ & & \\
\hline MBV & $0.732(0.000)$ & $-0.103(0.650)$ & 0.526 & 57 \\
\hline ROA & $0.725(0.000)$ & $0.264(0.973)$ & 0.525 & 57 \\
\hline ROE & $0.726(0.000)$ & $-0.150(0.967)$ & 0.525 & 57 \\
\hline ROIC & $0.721(0.000)$ & $-5.366(0.057)$ & 0.517 & 46 \\
\hline
\end{tabular}

Table 4 Westpac Bank RepuTex Ratings

\begin{tabular}{|l|c|c|c|c|c|}
\hline Year & Overall & Governance & Environment & Social & $\begin{array}{c}\text { Work } \\
\text { Place }\end{array}$ \\
\hline 2003 & AAA & G2 & E3 & S1 & W2 \\
\hline 2004 & AAA & G1 & E2 & S1 & W3 \\
\hline
\end{tabular}

Table 5 National Australia Bank RepuTex Ratings

\begin{tabular}{|c|c|c|c|c|c|}
\hline Year & Overall & Governance & Environment & Social & $\begin{array}{c}\text { Work } \\
\text { Place }\end{array}$ \\
\hline 2003 & A & G2 & E4 & S2 & W2 \\
\hline 2004 & AA & G3 & E2 & S2 & W2 \\
\hline
\end{tabular}

